\title{
Hubungan Antara Menonton Acara Kekerasan Televisi Dengan Perilaku Agresif Siswa SMP di Salatiga
}

\author{
Yosua Ivan Pradana \\ Program Studi S1 Bimbingan dan Konseling Universitas Kristen Satya Wacana \\ 132014070@student.uksw.edu \\ Yari Dwikurnaningsih \\ Magister Manajemen Pendidikan Universitas Kristen Satya Wacana \\ yari.dwikurnaningsih@staff.uksw.edu

\section{Setyorini} \\ Program Studi S1 Bimbingan dan Konseling Universitas Kristen Satya Wacana \\ setyorini@staff.uksw.edu
}

\begin{abstract}
This study aims to determine the significance of the relationship between watching the violence shown on television with aggressive behavior of junior high school students in Salatiga. The hypothesis put forward is that there is a significant relationship between watching television violence shows with aggressive behavior of junior high school students in Salatiga. The study was conducted in one of the junior high schools in Salatiga. Sampling technique in this research using stratified random sampling technique. The questionnaire used was a questionnaire of aggressive behavior of teenagers and questionnaires watching the violence on television. The analytical method used is Kendall's tau correlation technique. Based on the data analysis obtained correlation value 0.811 with a significance level of 0.000 ( $p<0.05)$. These results indicate that there is a significant relationship between watching the violence shown on television and the aggressive behavior of junior high school students in Salatiga. The higher the students watch the violence on television, the higher the aggressive behavior. Thus the hypothesis proposed in this study is accepted.
\end{abstract}

Keywords : Aggressive Behavior, Adolescents, Violence, Watching Television Shows

\section{Article Info}




\section{PENDAHULUAN}

Di era globalisasi saat ini, mayoritas generasi muda memunculkan perilaku yang merusak cerminan diri generasi muda, seperti tawuran/perkelahian antar pelajar. Banyak remaja yang tidak dapat mengontrol emosi mereka, sehingga berujung pada tindakan kekerasan dan perilaku agresif. Menurut Monks dkk, 1989 remaja sebenarnya tidak memiliki tempat yang jelas, mereka sudah tidak termasuk golongan anak-anak, tetapi belum juga dapat diterima secara penuh untuk masuk ke golongan orang dewasa. Remaja berada di antara anak dan orang dewasa, oleh karena itu remaja seringkali dikenal dengan fase "mencari jati diri" atau fase "topan dan badai". Remaja masih belum mampu menguasai dirinya sendiri dan terus mencari jati dirinya. Di masa pencarian jati diri ini, perilaku yang sering dilakukan oleh remaja adalah seperti berkelahi, berbicara kasar, menentang orang yang lebih tua, bullying, dan sebagainya, itu semua tergolong dalam perilaku agresif.

Menurut Saad (2008) perilaku agresif remaja merupakan perilaku yang dapat merugikan atau mencederai orang lain dan memiliki unsur kesengajaan. Contoh perilaku agresif yang sering terjadi adalah pemukulan, berkata kasar, menghina, dan perilaku agresif lainnya baik secara fisik maupun verbal. Selain itu, dalam prosesnya, remaja juga memperlihatkan perilaku mereka yang aktif menggunakan media massa, media massa menjadi sarana dalam gaya hidup sehari-hari. Menurut Sawono \& Meinarno (2012) media massa menjadi salah satu faktor yang dapat mempengaruhi perilaku agresif remaja. Terjadi demikian karena peran media massa yang semakin hebat dan kuat dalam mempengaruhi remaja. Media massa menjadi alat untuk mempermudah dalam pencarian informasi maupun ilmu pengetahuan kepada audience khusunya remaja. Media massa berkembang menjadi kelompok penekan.
Dalam hal ini, hidup remaja bergantung pada media massa, seperti kebutuhan sehari-hari, dan proses belajar remaja, itu semua ditentukan oleh media massa (Nurudin, 2014).

Media massa merupakan sarana menyampaikan informasi dan komunikasi secara massal. Media seperti televisi, koran, film, radio, dan internet dapat diakses dengan mudah oleh remaja. Menurut Kuswandi (2008), media televisi memiliki keistimewaan tersendiri. Televisi mampu menyampaikan informasi dengan menampilkan visual maupun audio secara nyata kepada penonton dalam waktu yang bersamaan, sehingga televisi menjadi media yang paling baik dan sangat mudah diingat oleh orang yang menonton. Sebagaimana dikatakan Sulaiman (dalam Hutapea, 2010) $75 \%$ pengetahuan manusia adalah melalui mata menuju ke otak dan selebihnya melalui indera-indera yang lainnya. Beberapa keistimewaan tersebut membuat media televisi menjadi pilihan pertama dalam mengakses informasi. Saat ini televisi menjadi perdebatan publik mengenai penayangan adegan kekerasan melalui acara berita, sinetron, sport, film dalam negeri maupun luar negeri, dan lain-lain. Menurut Krahe (2005), publik menganggap adegan tersebut dapat mempengaruhi peningkatan perilaku agresif remaja. Tinjauan Comstock dan Scharrer (dalam Krahe, 2005) menjelaskan bahwa terdapat kandungan agresif dan kekerasan di media televisi serta saluran televisi berlangganan (pay per view channel).

Menurut Hutapea (2010) remaja memiliki kemungkinan untuk meniru adegan kekerasan yang mereka saksikan di televisi (seperti bertindak kasar, membunuh, menggugurkan kandungan, perkelahian, mengganggu ketertiban, melanggar aturan, dan sebagainya). Seperti yang dijelaskan oleh Hanim (2005) bahwa manusia adalah makhluk imitatif. Perilaku meniru sangat terlihat pada masa remaja. Mereka menganggap kekerasan/perkelahian yang ditampilkan di 
televisi sesuai dengan sebenarnya serta sulit membedakan antara tayangan fiktif dengan kisah nyata.

Berita kejahatan dan kekerasan di media televisi menjadi berita top three saat ini. Berita kekerasan mempunyai nilai jual dan daya tarik yang tinggi. Dikatakan demikian karena sifat penonton yang senang dalam menyaksikan berita kekerasan. Menurut Freud (dalam Sawono dan Meinarno, 2012) manusia memiliki naluri kematian atau yang disebut naluri tanatos, yang merupakan naluri/dorongan untuk menghancurkan yang ada pada setiap manusia yang dinyatakan dalam perkelahian, pembunuhan, perang, sadisme, dan sebagainya. Menyaksikan dan menonton kekerasan di televisi menjadi salah satu cara manusia menyalurkan naluri kematian, dan bisa jadi, tayangan kekerasan menjadi efek naluri kematian muncul.

Remaja memiliki rentang usia $12-24$ tahun, oleh karena itu siswa SMP termasuk dalam golongan remaja, dan hal tersebut menjadi salah satu alasan peneliti akan melakukan penelitian ini di salah satu SMP di Salatiga. Peneliti telah mencari data awal dan melakukan observasi serta wawancara dengan guru BK, guru agama, dan siswa di SMP tempat peneliti melakukan penelitian. Guru BK memaparkan bahwa SMP ini memang memiliki "keistimewaan" dibanding SMP lain di Salatiga. Siswa-siswinya terkenal "nakal" dan itu sudah menjadi hal yang turun-temurun. Guru BK juga menjelaskan bahwa jarang mereka menemukan siswa yang membawa handphone ke sekolah karena mayoritas siswa di SMP ini berlatar belakang dari keluarga yang kurang mampu baik secara ekonomi maupun pendidikan. Siswa yang ditemui oleh peneliti juga mengakui bahwa mereka tidak memiliki handphone, kalaupun ada yang memiliki, tidak selalu online karena mereka tidak mampu untuk setiap saat membeli kuota internet. Pada akhirnya, televisi adalah media massa yang paling banyak mereka pergunakan/manfaatkan. Guru agama di SMP ini memberikan pernyataan yang hampir serupa, dan mengatakan bahwa tawuran, berkelahi, dan saling ejek serta membully adalah hal yang terasa "lumrah" di SMP ini.

Berdasarkan penelitian sebelumnya, terdapat kesenjangan dan dua opini yang berbeda. Rujukan pertama yakni penelitian yang dilakukan oleh Nando tahun 2011 dengan judul "Hubungan antara perilaku menonton acara kekerasan dengan perilaku agresi remaja". Penelitian tersebut menyimpulkan bahwa perilaku menonton film kekerasan tidak memiliki hubungan signifikan dengan perilaku agresi remaja. Ini berbanding terbalik dengan pendapat Andriadi dalam skripsinya yang berjudul "Hubungan Paparan Tayangan Kekerasan Dengan Perilaku Agresif Remaja di SMK Dr. Tjipto Ambarawa Kabupaten Semarang" pada tahun 2016, yang menyatakan ada hubungan antara paparan tayangan kekerasan dengan perilaku agresif pada remaja di SMK Dr. Tjipto Ambarawa.

Penelitian ini bertujuan untuk mengetahui signifikansi hubungan antara menonton acara kekerasan di televisi dengan perilaku agresif siswa SMP di Salatiga. Penelitian ini diharapkan dapat menjadi acuan untuk pengembangan program bimbingan dan konseling serta untuk mengetahui efek dari menonton acara kekerasan di televisi dan perilaku agresif, yang tentunya itu akan berguna untuk pihak-pihak terkait seperti guru BK, orangtua, dan lembaga pendidikan.

Perilaku adalah suatu kegiatan atau aktivitas organisme (makhluk hidup) yang bersangkutan. Perilaku manusia pada hakikatnya adalah tindakan atau aktivitas dari manusia itu sendiri yang mempunyai bentangan yang sangat luas antara lain : berjalan, berbicara, menangis, tertawa, bekerja, kuliah, menulis, membaca, dan sebagainya (Notoatmodjo, 2012).

Berdasarkan penjelasan tersebut, perilaku adalah segala tindakan atau aktivitas 
yang dilakukan oleh manusia, dapat berupa perilaku kognitif (perilaku yang menekankan aspek intelektual), perilaku afektif (perilaku yang menekankan aspek emosi perasaan), maupun perilaku psikomotor (perilaku yang menekankan aspek ketrampilan motorik).

Menurut Baron dan Richardson (dalam Krahe, 2005) mendefinisikan agresi sebagai suatu perilaku yang diwujudkan dalam berbagai bentuk yang dimaksudkan untuk menyakiti atau melukai makhluk hidup lain yang terdorong untuk menghindari perlakuan tersebut. Agresif merupakan setiap tindakan yang dimaksudkan untuk menyakiti atau melukai orang lain (Taylor, Peplau, \& Sears, 2009).

Menurut Agustina, Suprihatin, dan Rohmatun (2017), agresif memiliki makna yang berbeda-beda, yakni : (1) Agresif merupakan perilaku yang bertujuan untuk melukai orang lain; (2) agresif sebagai bentuk asertif, perilaku yang ditujukan untuk memenuhi keinginan seseorang; (3) agresif sebagai bentuk penegasan akan kekuasaan seseorang.

Jadi, menurut pengertian tersebut, peneliti sepakat bahwa agresi adalah tindakan / perilaku, dapat berupa fisik maupun verbal, yang sengaja dilakukan oleh seseorang atau kelompok dengan tujuan untuk melukai, menyakiti, memenuhi keinginan, penegasan kekuasaan, dan merugikan orang lain maupun kelompok lain.

Mac Neil dan Stewart (dalam Hanurawan, 2010) menjelaskan bahwa perilaku agresif adalah suatu perilaku atau suatu tindakan yang diniatkan untuk mendominasi atau berperilaku secara destruktif, melalui kekuatan verbal maupun kekuatan fisik, yang diarahkan kepada objek sasaran perilaku agresif. Objek sasaran perilaku meliputi lingkungan fisik, orang lain dan diri sendiri.

Anantasari (2006) menyebutkan enam ciri - ciri perilaku agresif sebagai berikut : a. Perilaku menyerang;

b. Perilaku menyakiti atau merusak diri sendiri, orang lain, atau objek-objek penggantinya;

c. Perilaku yang tidak diinginkan orang yang menjadi sasaranya;

d. Perilaku yang melanggar norma sosial;

e. Sikap bermusuhan terhadap orang lain;

f. Perilaku agresif yang dipelajari;

Menurut Koeswara (1998) ada beberapa faktor yang mempengaruhi terjadinya perilaku agresif, yaitu : (1) Kemiskinan; (2) Suhu udara; (3) Peran belajar model kekerasan; (4) Frustasi;

Kesenjangan generasi; (6) Amarah; (7) Proses pendisiplinan yang keliru; (8) Faktor biologis.

Menurut Restu dan Yusri (2013)

Perilaku Agresif bisa disebabkan oleh faktor merasa kurang diperhatikan, tertekan, pergaulan buruk, dan efek dari tayangan kekerasan di media massa.

Berdasarkan penjelasan tersebut, peneliti berpendapat bahwa faktor-faktor penyebab perilaku agresif dapat digolongkan menjadi dua yakni faktor internal (contoh : rasa frustasi, tertekan) dan faktor eksternal (contoh : kemiskinan, pergaulan yang buruk, dan media massa seperti televisi).

Buss \& Perry (1992) menjabarkan ada empat aspek perilaku agresif yaitu :

a. Physical Aggresion (agresi fisik)

Physical Aggresion merupakan agresi yang dapat diobservasi (terlihat). Physical Aggresion (PA) adalah kecenderungan individu untuk melakukan serangan secara fisik untuk mengekspresikan kemarahan atau agresi. Bentuk serangan fisik tersebut adalah memukul, mendorong, dan mencubit.

b. Verbal Aggresion (agresi verbal)

Verbal Aggresion merupakan agresi yang dapat dioservasi (didengar). Verbal Aggresion adalah kecenderungan menyerang orang lain untuk memberikan stimulus yang merugikan dan menyakitkan 
Hubungan Antara Menonton Acara Kekerasan Televisi Dengan Perilaku ... | Yosua I. Pradana, dkk.

kepada organisme lain secara verbal, yaitu melalui kata-kata atau penolakan. Bentuk serangan verbal adalah cacian, memfitnah, mengumpat, penolakan, ejekan, dan kata kasar.

c. Anger (kemarahan)

Anger adalah perasaan marah, kesal,

sebal dan bagaimana menontrol hal tersebut. Di dalamnya adalah mengenai temperamental, kecenderungan cepat marah, atau kesulitan mengendalikan amarah.

d. Hostility (permusuhan)

Hostility tergolong dalam agresi covert (tidak nampak). Hostility terdiri dari dua bagian yaitu Resentmen seperti cemburu dan iri hati terhadap orang lain, serta Suspicion seperti adanya ketidakpercayaan terhadap orang lain.

Kekerasan adalah segala sesuatu yang menyebabkan orang terhalang untuk mengaktualisasikan potensi diri secara wajar. Namun, penghalang itu adalah sesuatu yang dapat dihindarkan. Artinya, kekerasan dapat dihindarkan kalau penghalang itu disingkirkan (As'ad, 2000).

Menurut Chawazi (2001) tindak kekerasan sama juga pengertiannya dengan penganiayaan, yaitu perbuatan yang dilakukan dengan sengaja untuk menimbulkan rasa sakit atau luka pada tubuh orang lain. Dalam Kitab Undang-Undang Hukum Pidana pasal 351 (dalam Chazawi, 2001), penganiayaan atau tindak kekerasan adalah : (1) Setiap perbuatan yang dilakukan dengan sengaja untuk merugikan kesehatan orang lain; (2) Setiap perbuatan yang dilakukan dengan sengaja untuk memberikan penderitaan pada orang lain.

Dari pengertian kekerasan tersebut, peneliti menyimpulkan bahwa kekerasan adalah sebuah perilaku/perbuatan yang dilakukan secara sengaja, dapat dilakukan secara perorangan maupun banyak orang, serta menimbulkan penderitaan dan kerugian pada orang lain baik secara fisik maupun secara psikis. Namun, kekerasan itu sendiri sebenarnya dapat dihindarkan asalkan tahu faktor penyebab dari kekerasan tersebut terjadi.

Yayasan SEJIWA, dalam bukunya tentang bullying (2008), membagi bentuk kekerasan ke dalam dua jenis yaitu :

a. Kekerasan fisik; yaitu jenis kekerasan yang kasat mata. Siapapun bisa melihat karena terjadi sentuhan fisik antara pelaku dengan korban.

b. Kekerasan non-fisik; yaitu jenis kekerasan yang tidak kasat mata. Artinya, tidak bisa langsung diketahui perbuatannya karena tidak terjadi sentuhan fisik antara pelaku dengan korban. Kekerasan non-fisik dibagi menjadi dua yaitu kekerasan verbal serta kekerasan psikologis/psikis.

Galtung (dalam Eriyanti, 2017) membagi kekerasan menjadi "Segitiga Kekerasan" yaitu kekerasan langsung, struktural, dan kultural. Kekerasan langsung bisa terlihat secara nyata demikian pula dengan pelakunya. Kekerasan struktural melukai kebutuhan dasar manusia, tetapi tak ada pelaku langsung yang bisa diminta tanggung jawabnya. Sementara kekerasan kultural adalah legitimasi atas kekerasan struktural maupun kekerasan langsung secara budaya.

Berdasarkan penjelasan tersebut, kekerasan dapat dibagi dalam dua bentuk yakni secara fisik atau non-fisik, dan dapat terwujud secara langsung, secara terstruktur, maupun karena budaya / kultur yang dianut oleh suatu kelompok.

Dalam Yosep (2009), mengemukakan aspek perilaku kekerasan yakni : (1) Fisik; (2) Verbal; (3) Perilaku; (4) Emosi; (5) Intelektual; (6) Spiritual; (7) Sosial; (8) Perhatian.

Menurut Dwikurnaningsih (2015) media televisi efektif untuk mempengaruhi perilaku seseorang karena televisi mempunyai kemampuan : (1) fiksatif yaitu dapat 
menampilkan kejadian masa lampau; (2) manipulatif, yaitu kemampuan untuk memanipulasi kejadian yang tidak sebenarnya; (3) distributif, dapat menyebarkan informasi dalam waktu yang singkat dan dalam jangkauan yang luas.

Kekerasan adalah salah satu konten yang ada di media televisi. Berdasarkan lembaga sensor Indonesia, 95\% tayangan televisi di Indonesia mengandung unsur kekerasan. Kekerasan sepertinya akan sulit dihilangkan dari layar televisi, bahkan sekalipun usaha menguranginya dilakukan, namun kesan dominan kekerasan akan tetap muncul, karena kekerasan sendiri berperan sebagai bumbu penyedap dari sebuah cerita (Depari, 1995). Tingginya pengaruh televisi terhadap perilaku penontonnya membuat televisi dianggap sebagai penyebab dari maraknya tindak kekerasan yang terjadi di masyarakat, seperti perkelahian massa, tawuran, pemerkosaan, pembunuhan, perampokan, dan sebagainya.

\section{METODE PENELITIAN}

Penelitian ini menggunakan metode kuantitatif dengan jenis deskriptif korelasional. Metode Penelitian Kuantitatif, sebagaimana dikemukakan oleh Sugiyono (2012) yaitu metode penelitian yang berlandaskan pada filsafat positivisme, digunakan untuk meneliti pada populasi atau sampel tertentu, pengumpulan data menggunakan instrumen penelitian, analisis data bersifat kuantitatif/statistik, dengan tujuan untuk menguji hipotesis yang telah ditetapkan.

Penelitian deskriptif korelasional adalah penelitian yang diarahkan untuk menjelaskan hubungan antara dua variabel yaitu variabel bebas dengan variabel terikat (Notoatmodjo, 2002). Menurut Faenkel dan Wallen (2008) Penelitian deskriptif korelasional adalah suatu penelitian untuk mengetahui hubungan dan tingkat hubungan antara dua variabel atau lebih tanpa ada upaya untuk mempengaruhi variabel tersebut 60 sehingga tidak terdapat manipulasi variabel. Adanya hubungan dan tingkat variabel ini penting karena dengan mengetahui tingkat hubungan yang ada, peneliti akan dapat mengembangkannya sesuai dengan tujuan penelitian.

Populasi dalam penelitian ini adalah siswa kelas VII dan VIII salah satu SMP di Salatiga yang berjumlah 448 siswa. Penelitian ini tidak melibatkan kelas IX karena pihak sekolah memfokuskan siswa kelas IX untuk mengikuti ujian sekolah,ujian nasional, serta kegiatan lain pasca-ujian.

Dalam menentukan besarnya sampel, peneliti menggunakan tabel Krejcie (Sugiyono, 2011). Ukuran sampel ini didasarkan atas kesalahan 5\%, sehingga sampel yang diperoleh mempunyai kepercayaan $95 \%$ terhadap populasi. Mengacu pada tabel Krejcie, dengan jumlah populasi antara 440 sampai 460 maka sampel yang digunakan dalam penelitian ini sebanyak 198 siswa.

Metode pengambilan sampel dalam penelitian ini menggunakan stratified random sampling. Menurut Sugiyono (2012) stratified random sampling adalah teknik penentuan sampel pada populasi yang unsur-unsurnya berstrata secara proporsional dan tidak homogen. Berdasarkan penghitungan, dapat diketahui sampel dalam penelitian ini (dari total sampel 198 siswa) adalah 102 siswa kelas VII dan 96 siswa kelas VIII.

Teknik pengumpulan data dalam penelitian ini dilakukan dengan menggunakan angket. Terdapat dua angket yakni angket perilaku agresif dan angket menonton acara kekerasan di televisi. Angket perilaku agresif disusun berdasarkan teori Buss \& Perry (1992) dan angket menonton acara kekerasan di televisi disusun berdasarkan teori Yosep (2009) oleh peneliti.

Teknik pengolahan data yang dipergunakan adalah dengan perhitungan komputasi program SPSS (Statistical Package 
Hubungan Antara Menonton Acara Kekerasan Televisi Dengan Perilaku ... | Yosua I. Pradana, dkk.

for Social Science) yaitu program komputer statistik yang mampu memproses data statistik secara tepat dan cepat. Sementara teknik analisis dalam penelitian ini mempergunakan teknik kuantitatif dengan uji statistik yaitu dengan rumus korelasi Kendall's tau yang digunakan untuk mengkaji hubungan variabel bebas $(\mathrm{X})$ dengan variabel terikat $(\mathrm{Y})$.

\section{HASIL PENELITIAN DAN \\ PEMBAHASAN}

\section{Analisa Deskriptif}

Setelah data terkumpul, langkah pertama yakni dilakukan analisa deskriptif. Dari pengolahan dan perhitungan data secara statistik diperoleh hasil sebagai berikut :

Tabel 1. Distribusi Frekuensi Menonton Acara Kekerasan di Televisi

\begin{tabular}{ccccr}
\hline No. & $\begin{array}{c}\text { Rentang } \\
\text { Skor }\end{array}$ & Kategori & Frekuensi & Persentase \\
\hline 1 & $216-256$ & Sangat Tinggi & 49 & $24.7 \%$ \\
\hline 2 & $178-215$ & Tinggi & 70 & $35.3 \%$ \\
\hline 3 & $140-177$ & Sedang & 62 & $31.3 \%$ \\
\hline 4 & $102-139$ & Rendah & 15 & $7.6 \%$ \\
\hline 5 & $64-101$ & Sangat Rendah & 2 & $1.1 \%$ \\
\hline \multicolumn{6}{c}{ TOTAL } & 198 & $100 \%$ \\
\hline
\end{tabular}

Dari tabel sebaran distribusi frekuensi, dapat diketahui bahwa siswa yang menonton acara kekerasan di televisi berkategori sangat tinggi sebesar $24.7 \%$, kategori tinggi sebesar $35.3 \%$, kategori sedang sebesar $31.3 \%$, kategori rendah sebesar 7.6\%, dan kategori sangat rendah sebesar $1.1 \%$. Dari data sebaran frekuensi tersebut, dapat disimpulkan kegiatan menonton acara kekerasan di televisi 198 siswa salah satu SMP di Salatiga didominasi oleh kategori tinggi dengan persentase $35.3 \%$ (70 siswa).

Tabel 2. Distribusi Frekuensi Perilaku Agresif

\begin{tabular}{|c|c|c|c|c|}
\hline No. & $\begin{array}{c}\text { Rentang } \\
\text { Skor }\end{array}$ & Kategori & Frekuensi & Persentase \\
\hline 1 & $176-208$ & Sangat Tinggi & 27 & $13.6 \%$ \\
\hline 2 & $145-175$ & Tinggi & 111 & $56.1 \%$ \\
\hline 3 & $114-144$ & Sedang & 47 & $23.7 \%$ \\
\hline 4 & $83-113$ & Rendah & 13 & $6.6 \%$ \\
\hline 5 & $52-80$ & Sangat Rendah & 0 & $0 \%$ \\
\hline \multicolumn{3}{|c|}{ TOTAL } & 198 & $100 \%$ \\
\hline
\end{tabular}

Dari tabel sebaran distribusi frekuensi, dapat diketahui bahwa siswa yang berperilaku agresif berkategori sangat tinggi sebesar $13.6 \%$, kategori tinggi sebesar $56.1 \%$, kategori sedang sebesar $23.7 \%$, kategori rendah sebesar $6.6 \%$, dan kategori sangat rendah sebesar $0 \%$. Dari data sebaran frekuensi tersebut, dapat disimpulkan perilaku agresif 198 siswa salah satu SMP di Salatiga didominasi oleh kategori tinggi dengan persentase $56.1 \%$ (111 siswa).

Analisis Korelasi

Analisis korelasi menonton acara kekerasan di televisi dengan perilaku agresif dapat dilihat pada tabel berikut :

Tabel 3. Hasil Korelasi antara Menonton Acara Kekerasan di Televisi dengan Perilaku Agresif Correlations

\begin{tabular}{|c|c|c|c|}
\hline & & $\begin{array}{c}\text { Menont } \\
\text { on }\end{array}$ & Agresif \\
\hline $\begin{array}{ll} & \text { Menonton } \\
\text { Kendall' } & \\
\text { s tau_b } & \\
& \\
& \text { Agresif }\end{array}$ & $\begin{array}{l}\text { Correlation } \\
\text { Coefficient } \\
\text { Sig. (2-tailed) } \\
\mathrm{N} \\
\text { Correlation } \\
\text { Coefficient } \\
\text { Sig. (2-tailed) } \\
\mathrm{N}\end{array}$ & $\begin{array}{r}1.000 \\
. \\
198 \\
.811^{* *} \\
.000 \\
198\end{array}$ & $\begin{array}{r}.811^{\star *} \\
.000 \\
198 \\
1.000 \\
. \\
198\end{array}$ \\
\hline
\end{tabular}

Dari tabel tersebut, didapatkan nilai asymp sig. antara menonton acara kekerasan di televisi dengan perilaku agresif sebesar 0.000 $(<0.05)$ dan nilai asymp sig. antara perilaku agresif dengan menonton acara kekerasan di televisi sebesar $0.000(<0.05)$.

Uji Hipotesis

Uji hipotesis dilakukan dengan komputer program Statistical Package for Social Sciences (SPSS), menggunakan rumus korelasi Kendall's tau yang menguji hubungan menonton acara kekerasan di televisi dengan perilaku agresif remaja. Dari hasil analisis, didapatkan nilai asymp sig. antara menonton acara kekerasan di televisi dengan perilaku agresif sebesar $0.000(<0.05)$ dan nilai asymp 
sig. antara perilaku agresif dengan menonton acara kekerasan di televisi sebesar $0.000(<$ 0.05), yang menunjukkan ada hubungan yang signifikan antara menonton acara kekerasan di televisi dengan perilaku agresif siswa. Selain itu, berdasarkan tingkat hubungan menurut Sugiyono (2012), maka penelitian ini memiliki tingkat hubungan sangat kuat karena nilai korelasinya berada dalam interval $0.80-1.00$ yakni 0.811.

Hasil analisis tersebut menunjukkan bahwa hipotesis yang berbunyi "Ada hubungan yang signifikan antara menonton acara kekerasan televisi dengan perilaku agresif siswa SMP di salatiga" diterima. Hal itu berarti semakin tinggi siswa menonton acara kekerasan di televisi, maka semakin tinggi perilaku agresifnya, begitupun sebaliknya.

\section{Pembahasan}

Hasil analisis data menemukan ada hubungan yang signifikan antara menonton acara kekerasan di televisi dengan perilaku agresif siswa SMP di salatiga. Dengan demikian hipotesis yang diajukan peneliti diterima dengan nilai asymp sig. $=0.000(<$ 0.05), yang berarti semakin tinggi siswa menonton acara kekerasan di televisi maka semakin tinggi perilaku agresifnya.

Hasil yang diperoleh tersebut sesuai dengan teori Krahe (2005) yang menyatakan bahwa perilaku agresif remaja dipengaruhi oleh beberapa faktor yang salah satunya adalah menonton televisi. Acara televisi menampilkan adegan pemukulan, ejekan/bullying, pertengkaran, adu mulut, dan pengroyokan/tawuran yang terlihat sangat asli dan nyata. Menonton televisi memunculkan sebuah pandangan pada remaja bahwa perilaku agresif verbal maupun fisik adalah sesuatu yang normal dan boleh dilakukan.

Televisi memberikan pengaruh dalam peningkatan perilaku agresif (Sarwono \& Meinarno, 2012). Faktor menonton televisi memberikan kesempatan lebih pada audience untuk mengamati apa yang disampaikan secara jelas terutama adegan-adegan bertema kekerasan. Tayangan dari televisi memiliki potensi yang besar untuk ditiru pemirsa terutama pemirsa berusia remaja.

Televisi memiliki big influence terhadap perilaku karena remaja meniru apa yang disajikan dalam acara televisi. Remaja merasa bahwa yang disajikan dalam televisi adalah gambaran hidup sehari-hari. Penjelasan tersebut sejalan dengan eksperimen boneka bobo milik Bandura (dalam Sarwono \& Meinarno, 2012) yang menjelaskan bahwa perilaku agresif individu sebagai tingkah laku sosial yang dipelajari, dapat terbentuk hanya dengan menirukan atau mencontoh perilaku yang dilakukan oleh individu lain atau bahkan hanya mengamati sepintas dan tanpa penguatan. Individu lain yang diamati dalam penelitian ini adalah model atau tokoh dalam acara-acara televisi yang disaksikan remaja.

Menurut Leonard Eron dan Rowell Huesman (dalam Kuswandi, 2008), tayangan televisi memberikan dampak yang negatif bagi audience khususnya remaja. Acara televisi mulai berkembang dan tidak terkontrol, banyak adegan dan acara yang seharusnya tidak ditampilkan seperti, perkelahian, katakata kasar, memukul/menendang, dan adegan agresif lainnya. Masa remaja merupakan masa perkembangan dalam adaptasi diri dengan lingkungan/kehidupan sosial. Dengan menonton acara-acara di televisi, remaja menyesuaikan diri dengan hal-hal yang sedang populer di lingkungan sosial dan lingkungan teman sebaya (Hurlock, 2003).

Remaja adalah sosok yang cepat menyerap adegan-adegan yang mereka saksikan di televisi (Hanim, 2005). Remaja merupakan masa di mana muncul perilaku imitatif atau menirukan adegan-adegan di televisi yang interesting dan populer. Acaraacara di televisi saat ini banyak menampilkan scene yang mengandung agresivitas baik fisik maupun verbal, yang ditampilkan sangat 
natural dan nyata. Remaja menganggap adegan tersebut merupakan suatu hal yang wajar untuk diteladani dalam keseharian aktivitas mereka.

Menurut Dewi (2015) daya tarik remaja tentang kekerasan terletak pada viewpoint mereka dalam melihat adegan kekerasan di televisi. Jika remaja menganggap adegan kekerasan adalah hal yang mengasyikkan/menggembirakan, maka kekerasan di televisi merupakan hal yang wajar dan menarik untuk disaksikan. Remaja tertarik pada film maupun sinetron yang memunculkan adegan kekerasan sebagai pembelaan diri dan penyelesaian masalah karena hal tersebut menjadi "perwujudan" sesuatu yang benar dan mendapat penghargaan/reward atas perilaku tersebut, sehingga membuat tayangan kekerasan di televisi lebih menonjol untuk ditonton para remaja.

Menurut Koeswara (1998) acara di televisi memiliki dampak yang significant terhadap pembentukan dan atau peningkatan perilaku agresif bagi para penontonnya, khususnya penonton usia remaja yang sering menyaksikan acara-acara di televisi. Sejalan dengan Dewi (2015) yang menjelaskan adegan-adegan kekerasan di televisi yang diperankan oleh orang/sosok/tokoh yang diidolakan dapat menimbulkan pengajaran dalam berfantasi, bertingkah laku, mengeluarkan ide-ide, dan lainnya. Hal tersebut menjadi dasar remaja ingin menirukan adegan kekerasan. Remaja mempunyai persoalan yang serupa dengan tokoh di televisi, maka remaja tersebut akan melakukan kekerasan baik fisik maupun verbal seperti sosok yang dilihatnya, yaitu membully, memarahi, memukul, dan berkata-kata kasar. Kekerasan menjadi cara untuk memecahkan masalah dan persoalan di kehidupan nyata serta untuk membenarkan perilaku kekerasan seperti yang tokoh idola lakukan di televisi.

Hasil analisis data yang dilakukan menunjukkan bahwa mean hipotetik $(\mathrm{MH})$ perilaku agresif remaja adalah sebesar 130 dengan SDh sebesar 26 dan mean empiric (ME) 186.29. Hasil menunjukkan bahwa perilaku agresif pada siswa salah satu SMP di Salatiga tergolong cukup tinggi. Hal ini berarti bahwa siswa-siswi salah satu SMP di Salatiga memiliki kecenderungan berperilaku kurang disiplin dan melanggar norma-norma yang ada. Tetapi, meskipun demikian, perilaku agresif siswa masih dalam batas wajar dan tidak masuk dalam level yang sangat berbahaya. Para siswa masih bisa diarahkan untuk memperbaiki perilakunya, meskipun masih terdapat perilaku agresif yang muncul disaat siswa tidak dapat mengendalikan emosi. Rutinnya kegiatan berdoa sebelum pelajaran, siswa yang menyapa dan berjabat tangan dengan guru, serta kegiatan sekolah lain yang berbasis kedisiplinan dan keagamaan, menunjukkan para siswa tidak memiliki perilaku agresif yang sangat tinggi.

Analisis lebih lanjut menunjukkan bahwa menonton acara kekerasan di televisi memiliki mean hipotetik (MH) sebesar 160 dengan SDh sebesar 32 dan mean empiric (ME) sebesar 153.86. Hasil menunjukkan bahwa menonton acara kekerasan di televisi pada siswa salah satu SMP di Salatiga tergolong sedang. Golongan tersebut dapat diartikan bahwa siswa tidak selalu menonton acara-acara kekerasan di televisi. Hal ini dikarenakan tidak hanya kekerasan yang selalu muncul selama siswa menonton televisi, namun juga terdapat adegan dan acara lainnya yang muncul di berbagai channel televisi, seperti hiburan edukasi, promosi barang (online, jual-beli dsb), dan iklan. Hal ini sesuai dengan pandangan Badjuri (2010) bahwa televisi menayangkan acara seperti iklan, kartun, infotaiment, dan reality show yang acara-acara tersebut secara keseluruhan tidak selalu mengandung unsur agresif fisik maupun verbal. 


\section{SIMPULAN DAN SARAN \\ Simpulan}

Berdasarkan hasil penelitian dan pembahasan dapat disimpulkan bahwa ada hubungan yang signifikan antara menonton acara kekerasan di televisi dengan perilaku agresif siswa. Hasil penelitian ini sejalan dengan penelitian yang dilakukan oleh Andriadi, dan tidak sejalan dengan penelitian yang dilakukan oleh Nando.

Hal ini dibuktikan dari hasil analisis korelasional diperoleh nilai korelasi 0.811 dengan taraf signifikansi $0.000(\mathrm{p}<0.05)$. Hasil itu dapat diartikan semakin tinggi siswa menonton acara kekerasan di televisi, maka semakin tinggi pula perilaku agresif siswa, dan sebaliknya, semakin rendah siswa menonton acara kekerasan di televisi, maka semakin rendah pula perilaku agresif siswa.

\section{Saran}

Berdasarkan kesimpulan dari peneliti dapat diberikan saran sebagai berikut :

1. Bagi siswa yang melakukan agresif verbal sebaiknya untuk lebih sopan dalam berkomunikasi atau berbicara terhadap orang lain, dengan cara meminta nasihat dan saran dari teman, orang terdekat, orang tua dan guru, serta belajar untuk lebih berfikir positif kepada orang lain.

2. Bagi orangtua dan keluarga hendaknya mendampingi anak-anak dalam menonton televisi dan memberikan wacana tentang pengaruh buruk menonton acara kekerasan, serta memberikan perhatian lebih kepada anak yang seusia remaja untuk mencegahan munculnya perilaku agresif pada remaja.

3. Bagi sekolah dan guru BK dapat memberikan informasi tentang dampak menonton acara kekerasan di televisi bagi remaja terutama dalam kaitannya dengan perilaku agresif remaja, baik dalam tatap muka di kelas, maupun melalui sosialisasi dengan melibatkan pihak luar yang terkait. Selain itu sekolah dapat menambah kegiatankegiatan non-formal yang bertujuan untuk menyalurkan bakat dan talenta siswa.

4. Bagi peneliti selanjutnya yang tertarik untuk meneliti perilaku agresif dapat melanjutkan dengan mempertimbangkan faktor-faktor lain seperti pola asuh orang tua, lingkungan tempat tinggal, jenis kelamin, teman sebaya dan pendidikan, sehingga yang bersangkutan dapat mengetahui lebih banyak hal-hal yang memengaruhi perilaku agresif remaja.

\section{DAFTAR PUSTAKA}

Agung, Dwi. Bakhtiar, J. \& Matulessy, Andik. 2012. Kecerdasan Emosi, Kecerdasan Spiritual, dan Agresivitas Pada Remaja. Jurnal Psikologi Indonesia

Agustina, Erni. Suprihatin, Titin. \& Rohmatun. 2017. Gambaran Agresifitas Anak dan Remaja di Area Beresiko. Jurnal Unissula

Anantasari. 2006. Menyikapi Perilaku Agresif Anak. Yogyakarta : Kanisius

As'ad. 2000. Perilaku Kekerasan. Jurnal Buletin Psikologi UGM.

Badjuri, A. 2010. Jurnalistik Televisi. Yogyakarta : Graha Ilmu

Baron, R.A \& Byrne, D. 2005. Psikologi Sosial. Jakarta : Erlangga

Buss, A.H \& Perry, M. 1992. The Aggresion Questionnaire. Journal of Personality and Social Psychology. The American Psychological Association, Inc.

Chawazi, Adami. 2001. Hukum Pidana Bagian I. Jakarta : Raja Grafindo Persada

Dewi, I.C. 2015. Pengantar Psikologi Media. Jakarta : Prestasi Pustakaraya 
Hubungan Antara Menonton Acara Kekerasan Televisi Dengan Perilaku ... | Yosua I. Pradana, dkk.

Depari, Edward \& Collin Mac Andrew. 1995.

Peranan Komunikasi Massa Dalam

Pembangunan. Yogyakarta : Gadjah

Mada University Press

Dwikurnaningsih, Yari. 2015. The Model of

Assessment-Competencies-Based

Training Management Using E-

Learning for Guidance and Counseling

Teachers. Online International

Interdisciplinary Research Journal

Eriyanti, L.D. 2017. Pemikiran Johan Galtung

Tentang Kekerasan dalam Perspektif

Feminisme. Jurnal Hubungan

Internasional Universitas Jember

Fraenkel, J.P \& Wallen N.E. 2008. How to Design and Evaluate Research in

Education. New York : McGraw-Hill

Companies, Inc.

Hanim, Diffah. 2005. Menjadikan UKS Sebagai Upaya Promosi Tumbuh Kembang Anak Didik. Yogyakarta : Gadjah Mada University Press

Hanurawan, Fattah. 2010. Psikologi Sosial : Suatu Pengantar. Bandung : Penerbit Rosda

Hurlock, E. 2003. Psikologi Perkembangan : Suatu Pendekatan Sepanjang Rentang Kehidupan. Jakarta : Erlangga

Hutapea, Albert M. 2010. Lingkup dan Mekanisme Pengaruh TV Atas Jiwa, Psikososial, dan Fungsi Kognitif Otak Anak (presentasi). Konferensi Mengenai Isu-Isu Anak di Indonesia

Koeswara, S. 1998. Agresi Manusia. Bandung : PT. Eresco

Krahe, Barbara. 2005. Perilaku Agresif. Yogyakarta : Pustaka Pelajar

Kuswandi, Wawan. 2008. Komunikasi Massa (sebuah analisis isi media televisi). Jakarta : Rineka Cipta
Monks, F.J. 1989. Psikologi Perkembangan. Yogyakarta : Gadjah Mada University Press

Mulkan, Dede. 1997. Pengantar Ilmu Jurnalistik. Bandung : Arsad Press

Myers, David G. 2012. Psikologi Sosial Edisi Sepuluh, Buku 2. Jakarta : Salemba Humanika

Notoatmodjo, Soekidjo. 2012. Promosi Kesehatan dan Perilaku Kesehatan. Jakarta : Rineka Cipta

Notoatmodjo, Soekidjo. 1993. Pendidikan Kesehatan dan Ilmu Perilaku Kesehatan. Yogyakarta : Andi Offset

Nurudin. 2014. Pengantar Komunikasi Massa. Jakarta : Rajawali Press

Restu, Yoshi \& Yusri. 2013. Studi Tentang Perilaku Agresif Siswa di Sekolah. Jurnal Ilmiah Konseling UNP

Sarwono, Sarlito W. \& Eko A. Meinarno. 2012. Psikologi Sosial. Jakarta : Salemba Humanika

SEJIWA. 2008. Bullying : Mengatasi Kekerasan di sekolah dan lingkungan. Jakarta : Grasindo

Sugiyono. 2012. Metode Penelitian Kuantitatif Kualitatif dan $R \& D$. Bandung : Alfabeta

Sugiyono. 2011. Metode Penelitian Kuantitatif Kualitatif dan $R \& D$. Bandung : Alfabeta

Taylor, Shelley E., Letitia Ane Peplau, \& David O. Sears. 2009. Psikologi Sosial Edisi Kedua Belas. Jakarta : Kencana Prenada Media Group

Yosep, Iyus. 2009. Keperawatan Jiwa (Edisi Revisi). Bandung : PT. Refika Aditama 